\title{
Intangibles and the Gender Wage Gap
}

An analysis of gender wage gaps across occupations in the Finnish private sector

Rita Asplund ${ }^{*}$ - Sami Napari ${ }^{* *}$

* ETLA - Elinkeinoelämän Tutkimuslaitos, rita.asplund@etla.fi

* ETLA - Elinkeinoelämän Tutkimuslaitos, sami.napari@etla.fi 
Acknowledgements: This study is part of the so-called INNODRIVE project (No. 214576) funded within the 7th Framework Programme of the European Commission. We wish to thank participants at the INNODRIVE workshops for comments and suggestions. We are especially grateful to Pekka Vanhala for his excellent research assistance. The usual disclaimer applies.

ISSN 0781-6847 


\section{Contents}

$\begin{array}{lr}\text { Abstract } & 2\end{array}$

1 Introduction 3

2 Estimation method 5

$3 \quad$ Data and descriptive results $\quad 7$

4 Sources underlying the observed gender wage gaps - wage decomposition results 11

5 Conclusions 17

$\begin{array}{ll}\text { References } & 20\end{array}$

$\begin{array}{ll}\text { Appendix } & 22\end{array}$

Description of variables used in the estimations 24 


\section{Tiivistelmä}

Aikaisemmat tutkimukset ovat osoittaneet aineettoman pääoman olevan tärkeä talouskasvun ja tuottavuuden lähde. Tutkimuksissa on lisäksi havaittu aineettoman pääoman vaikuttaneen merkittävällä tavalla palkkarakenteisiin ja niissä tapahtuneisiin muutoksiin viime vuosina. Tämä tutkimus täydentää aikaisempaa kirjallisuutta aineettoman pääoman palkkavaikutuksista tarkastelemalla aineettoman pääoman merkitystä sukupuolten palkkaerojen taustalla Suomen yksityisellä sektorilla. Tutkimus vertailee sukupuolten palkkaeroja ja niissä tapahtuneita muutoksia vuosina 2002 ja 2009 erikseen teollisuuden toimihenkilöiden ja yksityisen palvelusektorin työntekijöiden osalta. Lisäksi tutkimuksessa jaetaan henkilöt tehtävänimikkeiden perusteella kahteen ryhmään: ICT-, T\&K, johto- tai markkinointitehtävissä toimivat ja kaikki muut työntekijät. Tämä eri henkilöstöryhmien yksityiskohtaisempi tarkastelu sektoreittain osoittautuu tärkeäksi, sillä havaitsemme huomattavia eroja sekä sektoreiden että työntekijäryhmien välillä sukupuolten keskimääräisissä palkkaeroissa, sukupuolten palkkaerojen vaihtelussa palkkajakauman eri osissa ja sukupuolten palkkaeroissa tapahtuneissa muutoksissa tarkasteluajanjakson aikana. Tuloksemme viittaavat edelleen siihen, että havaittujen erojen taustalla sektorikohtaiset tekijät ovat keskeisessä asemassa, joskaan työntekijäryhmäkohtaiset tekijät eivät ole täysin vailla merkitystä. Tästä syystä aineettoman pääoman vaikutusten tutkiminen sukupuolten välisiin palkkaeroihin vertailemalla eri työntekijäryhmiä ilman, että samanaikaisesti kiinnitetään huomiota sektoriin, saattaa johtaa vääriin johtopäätöksiin aineettoman pääoman tärkeydestä miesten ja naisten välisissä palkkaeroissa.

Asiasanat: Sukupuolten väliset palkkaerot, hajotelma, inhimillinen pääoma, aineeton pääoma, kvantiiliregressio, palkan muodostus, palvelualat, teollisuus

\section{Abstract}

The paper compares the gender wage differentials of two occupation groups - innovation and non-innovation workers - separately for manufacturing and services using Finnish private-sector data. We apply a decomposition method based on unconditional quantile regression techniques to identify key factors underlying the gender wage gaps observed along the whole wage distribution, as well as changes in these wage gaps between 2002 and 2009. This more nuanced approach provides important new insights. We find conspicuous differences in average gender wage gaps, in gender wage-gap profiles across the wage distribution and also in the evolution of gender wage differentials over time between sectors and occupation groups. Our results imply that sector-specific factors are a more important driving force behind these differences in patterns and trends of gender wage gaps, although occupationspecific factors cannot be totally dismissed. Hence, comparisons of gender wage gaps, including their underlying sources, of innovation and non-innovation workers for too broadly defined segments of the labour market may result in misleading conclusions concerning the factual role of intangible capital.

Key words: Gender wage gap, decomposition, human capital, intangible capital, quantile regression, wage formation, services, manufacturing

JEL: J16, J31 


\section{Introduction}

In recent years, as the developed economies have become increasingly knowledge-based, economists have shown growing interest in the role of intangible capital as a determinant of economic growth. Several studies report that intangible capital has had a significantly positive effect on both labour productivity growth and GDP growth rates over the past decades (e.g. Corrado et al., 2006; Jalava et al., 2007; Marrano et al., 2007). Corrado et al. (2006), for example, find that intangible capital accounts for some 27 per cent of US labour productivity growth in 1995-2005.

The marked impact of intangible capital on labour productivity growth invites one to ask, whether the growing role of intangible capital has possibly influenced wage formation as well. There is, in effect, a considerable amount of prior research on the impact of information and communication technologies (ICT) - an important component of intangible capital - on wage structures (e.g. Krueger, 1993; Lee and Kim, 2004; Beaudry and Green, 2005). Many studies report evidence in support of ICT usage having affected wage structures through, inter alia, increased returns to education (e.g. Kirby and Riley, 2007). The rise in returns to skills induced by technological change (often referred to as skill-biased technological change) is, indeed, one of the most frequently cited explanations for the increase in wage inequality observed in many countries over the past few decades (e.g. Beaudry and Green, 2005).

An interesting aspect related to the impact of intangible capital on wage formation concerns the potential effect of intangibles on gender wage gaps. Although there are several reasons why intangible capital might affect men's and women's wages differently, the existing empirical literature on this particular topic is still scant, if not non-existent. One plausible channel through which intangible capital may affect male-female wage differentials is labour market segregation. A broad literature on gender segregation shows that men and women tend to work in different industries, firms, occupations and job tasks (e.g. Meyersson Milgrom et al., 2001; Korkeamäki and Kyyrä, 2006). Given that industries and firms differ in their investments in intangible assets and, hence, in their occupation and job-task structures, the influence of intangible capital on wage levels and trends is not necessarily gender-neutral. Furthermore, there is ample evidence showing that women tend to accumulate less human capital than men due to their traditional role of being the main provider of child care within the family (Waldfogel, 1998; Anderson et al., 2003). Accordingly, intangible capital can be expected to widen wage differentials across genders to the extent it boosts rates of return on human capital investment.

A recent paper by Moreno-Galbis and Wolff (2008) is one of few empirical studies having analyzed the impact of ICT on male-female wage differentials. They compare gender wage gaps of ICT-users and non-ICT-users by applying quantile regression as well as differences-in-differences methods to survey data from France. Their results indicate that the gender wage gaps are similar for both worker groups; the wage advantage of men over women increases in a similar way along the wage distribution for both ICT-users and non-ICT-users. However, when examining the sources underlying these gender wage gaps, they find clear-cut differences between the two groups. Among ICT-users, the gender wage gap emerges because women are typically paid less than men for the various background characteristics accounted for in their analysis. Among non-ICT-users, on the other hand, this holds true only for the upper half of the wage distribution. Further down the wage distribution, the wage gap between male and female nonICT-users is explained mainly by gender differences in these characteristics. 
Our paper contributes to the vast empirical literature on gender wage gaps (for comprehensive reviews, see e.g. Altonji and Blank, 1999; Blau and Kahn, 2000; Kunze, 2008) in four distinct ways. First, by exploring the impact of intangible capital on gender wage differentials in the Finnish private sector over the period 2002 to 2009, it adds to the scarce present-day evidence within this particular field of research using, moreover, very recent data. However, as will become evident later on, we adopt a more comprehensive definition of intangible capital than do, for instance, Moreno-Galbis and Wolff (2008).

Second, our paper provides a more nuanced picture than hitherto of the role of intangible capital in explaining gender wage differentials in that we perform our analysis separately for white-collar manufacturing workers and services sector workers. ${ }^{1}$ Distinguishing between private-sector manufacturing and services can be justified on several grounds: distinct differences in the role and composition of intangible capital, as well as in wage structures and gender wage gaps. More specifically, while the level of intangible capital investments in Finland has exceeded the average EU-15 level in the period 1995-2005 (Roth and Thum, 2010) implying that the ICT revolution has been particularly pronounced in Finland (Koski et al., 2002), the implications have been much stronger for services than for manufacturing (Maliranta and Rouvinen, 2003). Additionally, while both white-collar manufacturing workers and services sector workers have experienced a marked growth in wage dispersion, the factors underlying this development have been clearly different in nature (Asplund, 2010). In particular, the widening wage differentials among services sector workers have been driven by a combination of changing characteristics and changes in the way these characteristics are rewarded in the labour market, whereas the latter explanation is overwhelming in the category of white-collar manufacturing workers. Finally, these two worker groups display differences also in the evolution of the average gender wage gap: among white-collar manufacturing workers it narrowed by more than 15 per cent between 2002 and 2009 (from 24.0 to 20.2 per cent) but among services sector workers by only some 7 per cent (from 28.8 to 26.7 per cent). Also the variation in the male-female wage gap along the wage distribution is highly different between the two worker groups. Among white-collar manufacturing workers, the variation ${ }^{2}$ around the average gender wage gap was, in 2009 , only some six percentage points compared to as much as 31.6 percentage points in the category of services sector workers. Finally, differentiating between white-collar manufacturing workers and services sector workers is well grounded also in view of the evidence provided in the earlier gender wage-gap literature showing that changes in the wage structure might have substantial effects on the gender wage gap (e.g. Blau and Kahn, 1997; Datta Gupta et al., 2006).

Third, in addition to basic measures of human capital endowments, notably education and work experience, we also introduce less frequently used intangible capital related measures: the share of innovation workers in each branch, the share of innovation workers in each company, the average years of schooling of each company's workforce, and company size. By extending our set of control variables beyond traditional measures of human capital, we are able to assess the potential impact of also other types of intangible capital on the gender wage gaps prevailing in manufacturing and services sector jobs.

\footnotetext{
We have also data on blue-collar workers in manufacturing. The main reason for excluding blue-collar workers from our analysis is that the occupational classification system for this worker category does not allow blue-collar workers to be classified in a similar way as white-collar manufacturing workers and services sector workers.

2 This refers to the difference in the gender wage gap between the $10^{\text {th }}$ and $90^{\text {th }}$ percentiles.
} 
A fourth major contribution of our paper is that we apply an elaborated decomposition method developed by Melly (2005a, 2005b, 2006). This methodology, which is based on unconditional quantile regression techniques, allows the overall gender wage gap to be decomposed along the whole range of the wage distribution and not only at the mean (as is the case when using more traditional decomposition methods like those of Blinder (1973) and Oaxaca (1973)). A decomposition along the whole wage distribution can be expected to provide important new information given the existing evidence of increasing gender wage gaps when moving up through the wage distribution (e.g. Albrecht et al., 2003; Arulampalam et al., 2007; Napari, 2009). Despite their great potential, decomposition procedures based on quantile regression have so far been used only limitedly in studies of gender wage gaps (see e.g. Chzhen and Mumford (2009) and the references therein).

The rest of the paper is organized as follows. The next section provides a brief outline of the applied decomposition method. Section 3 introduces the data used and presents descriptive statistics on levels and trends of worker- and occupation-specific gender wage gaps. This is followed, in Section 4, by a discussion of the decomposition results obtained. Section 5 summarizes our main conclusions.

\section{$2 \quad$ Estimation method}

We investigate and compare gender wage gaps across worker and occupation groups using an estimation method which comprises three steps. ${ }^{3}$ First, conditional wage distributions are estimated by use of quantile regression techniques. The second step includes estimation of the corresponding unconditional distributions by integrating the first-step conditional wage distributions over the full range of background characteristics accounted for in the quantile regressions. The final step decomposes the estimated counterfactual wage distributions into two components with respect to gender: one which captures the contribution to the observed gender wage gaps of differences across genders in estimated coefficients (i.e. the price effect) and one which measures the contribution of gender differences in characteristics (i.e. the composition effect). Each step is next described in a more detailed manner.

Regarding the first step - i.e. the estimation of the full conditional wage distributions using quantile regression techniques - assume, following Koenker and Bassett (1978), that ${ }^{4}$

$$
\left.F_{y \mid x}^{-1}\left(\tau \mid x_{i}\right)=x_{i} \beta(\tau), \quad \forall \tau \in\right] 0,1[
$$

where $F_{y \mid x}^{-1}\left(\tau \mid x_{i}\right)$ is the $\tau^{\text {th }}$ quantile of the log wage distribution $y$ conditional on a vector of characteristics $x_{i}$ with $\left(y_{i}, x_{i}\right)$ representing an independent sample $i=1, \ldots, N$ drawn from some population. As further shown by Koenker and Bassett (1978), $\beta(\tau)$ in eq. (1) can be estimated, separately for each quantile $\tau$, by

$$
\widehat{\beta}(\tau)=\underset{b \in R^{K}}{\arg \min } \frac{1}{N} \sum_{i=1}^{N}\left(y_{i}-x_{i} b\right)\left(\tau-1\left(y_{i} \leq x_{i} b\right)\right),
$$

\footnotetext{
For a more detailed outline of the method, see e.g. Machado and Mata (2005) and Melly (2005a, 2005b, 2006).

4 The notation is simplified by suppressing the dependence on the gender dimension. The notation ]0,1[ in eq. (1) indicates that, formally, the quantile regression is not defined at 0 or 1 , implying that $0<\tau<1$.
} 
where $1($.$) is the indicator function. Since the dependent variable is the (natural) logarithm of$ wages, eq. (2) produces a vector of coefficients which can be interpreted as wage effects of the different characteristics at a particular quantile of the conditional wage distributions estimated.

From eq. (1) it is clear that an infinite number of quantile regressions could be estimated, but with a large dataset, such as the one used in our paper, the estimation of the whole quantile regression process would be too time consuming. Instead, we estimate a specific number of quantile regressions uniformly distributed over the wage distribution. It is thereby assumed that the solution only changes at these specific points, not on the interval between the points. This procedure results in a finite number of quantile regression coefficients,

$\widehat{\beta}\left(\tau_{1}\right), \ldots, \widehat{\beta}\left(\tau_{j}\right), \ldots, \widehat{\beta}\left(\tau_{J}\right)$ for $j=1, \ldots, J$.

In the second step, estimates of unconditional quantiles, $\theta$, of the log wage distribution, $y$, are derived by replacing each conditional estimate $F_{y \mid x}^{-1}\left(\tau_{j} \mid x_{i}\right)$ by its consistent estimate $x_{i} \beta\left(\tau_{j}\right)$. Thus, the $\theta^{\text {th }}$ quantile of the log wage distribution can be estimated by

$$
\hat{q}(\widehat{\beta}, x)=\inf \left\{q: \frac{1}{N} \sum_{i=1}^{N} \sum_{j=1}^{J}\left(\tau_{j}-\tau_{j-1}\right) 1\left(x_{i} \hat{\beta}\left(\tau_{j}\right) \leq q\right) \geq \theta\right\},
$$

where taking the infimum ensures that the finite sample solution is unique.

In the final step, we use the procedure for simulating the whole counterfactual distribution described above to decompose the overall gender wage gap along the whole range of the wage distribution into one part capturing the effects of gender differences in estimated coefficients and another part measuring the contribution of gender differences in characteristics. If we assume that the linear quantile regression model is correctly specified, the residual component in the decomposition of the wage differentials observed between male $(m)$ and female $(f)$ workers vanishes asymptotically, and the resulting decomposition can be written as ${ }^{5}$

$$
\widehat{q}\left(\hat{\beta}^{m}, x^{m}\right)-\widehat{q}\left(\widehat{\beta}^{f}, x^{f}\right)=\left(\widehat{q}\left(\widehat{\beta}^{m}, x^{m}\right)-\widehat{q}\left(\widehat{\beta}^{f}, x^{m}\right)\right)+\left(\widehat{q}\left(\widehat{\beta}^{f}, x^{m}\right)-\widehat{q}\left(\widehat{\beta}^{f}, x^{f}\right)\right),
$$

where the first term on the right-hand side of eq. (4) measures the price effect, that is, the contribution of men and women being differently rewarded in the labour market for similar background characteristics (gender differences in coefficients), whereas the second term captures the component effect, that is, the contribution of gender differences in these same characteristics.

In Section 4, we focus entirely on reporting major results from the final estimation step only, that is, from the decomposition of the male-female wage differentials observed for the specific worker and occupation groups under scrutiny. The decomposition of these overall gender wage gaps is undertaken by use of the Stata command rqdeco coded by Melly (2006). More precisely, the gender wage-gap decomposition results reported in Section 4 are obtained by estimating a grid of 100 different quantile regressions distributed uniformly between the two tails of the wage distribution or, more formally, between 0 and 1 . In order to keep the processing time reasonable, a 50 per cent random sample is drawn from the total dataset available, leaving the sample still large enough to produce precise estimation results.

\footnotetext{
As will become evident later on, the effect of the residuals is, indeed, persistently negligible thus indicating the good fit of the models estimated.
} 


\section{Data and descriptive results}

We use data extracted from the full records of the Confederation of Finnish Industries EK, the leading business organization in Finland. EK collects its data by sending annual surveys to its member companies. It is mandatory for the company to respond to the survey and, consequently, the non-response bias is practically non-existent. Furthermore, the EK data is based on the administrative records of member companies, which guarantees that the information gathered is of high quality. This, together with the fact that the coverage of the EK database is fairly broad, comprising roughly half of all private-sector employees in Finland ${ }^{6}$, provides an excellent starting point for the analysis of gender wage gaps across worker and occupation groups.

The EK data used in the subsequent analysis is restricted to those in full-time employment ${ }^{7}$; that is, to white-collar manufacturing workers and services sector workers who can be assessed to be firmly attached to the labour market. The exclusion of part-time workers has a minor effect on the total number of observations for white-collar manufacturing workers, as most of them are employed on a full-time basis. For instance, in 2009 only 2.2 per cent of male white-collar workers and 3.0 per cent of female white-collar workers held a part-time job. The situation is very different in private-sector services, where a considerable portion is part-time workers: 12.5 per cent of men and 21.3 per cent of women according to figures for 2009 . However, these individuals are for the most part young people working in retail trade while studying. As the sector's part-time workers typically seem to have a rather loose attachment to the labour market, the inclusion of them would probably have spurious effects on the estimation results for services. Therefore, excluding all part-time workers from the analysis is wellgrounded.

Additionally, we confine our data on white-collar manufacturing workers and services sector workers to those aged 18 to 64 . We also exclude a small number of observations with suspiciously low or high wages (obviously due to coding errors). The final dataset contains 322,402 observations in total for white-collar manufacturing workers, out of which 33.6 per cent are women. For the services sector we have a total of 387,180 observations with the female share being 65.8 per cent.

The wage measure applied refers to the total hourly wage deflated by the official consumer price index (CPI). ${ }^{8}$ Total hourly wages are calculated from information on each individual's total monthly earnings and regular (normal) weekly working hours. The wage measure thus includes not only basic monthly earnings, but also various types of bonuses (such as merit pay) and possible fringe benefits.

We investigate the impact of intangible capital on male-female wage differentials by splitting each worker group - white-collar manufacturing workers and services sector workers - into two broad occupation categories, which we then compare with respect to levels and trends in the gender wage gap. Individuals performing either ICT- or R\&D-related job tasks, as well as

\footnotetext{
EK represents the entire private sector, both industry and services, and companies of all sizes. Its about 16,000 member companies, of which 95 per cent are SMEs, cover over 70 per cent of Finland's GDP and over 95 per cent of the country's exports. The member companies have about 950,000 employees. See further http://www.ek.fi/www/en/index.php

By full-time workers we mean those whose regular (normal) weekly working hours are at least 30 hours.

8 Wages are converted into year 2005 money.
} 
individuals involved in the production of organizational competencies - i.e. management and marketing - are labelled innovation workers. ${ }^{9}$ All other workers are classified as non-innovation workers. In other words, following Görzig et al. (2011) we adopt a slightly broader definition of workers engaged in activities related to intangible capital than, for instance, MorenoGalbis and Wolff (2008). ${ }^{10}$

Table 1 gives descriptive statistics for the average total hourly wage of the full-time white-collar manufacturing and services sector workers covered by our dataset. In what follows, we focus on the differences in wages observed across genders while paying particular attention to how these differences vary across worker and occupation groups. In this respect, Table 1 unravels several distinct features. Among white-collar manufacturing workers, the gender wage gap is, on average, larger in innovation than in non-innovation occupations. During the time period investigated, it has narrowed only marginally, albeit slightly more in innovation than in non-innovation occupations. While the difference in the average female-over-male wage ratio between the two occupation categories was 5 percentage points in 2002, it had shrunk to 4 percentage points by 2009 .

The situation is basically the opposite in private-sector services. More precisely, the gender wage gap is, on average, larger for non-innovation than innovation workers. The average gender wage gap of non-innovation workers has remained practically unchanged, whereas the sector's innovation workers have seen a further narrowing in their average wage differential across genders. As a consequence, the difference in the average female-over-male wage ratio between the two occupation categories increased between 2002 and 2009, from 4 to 8 percentage points. Taken together, these features had by 2009 resulted in a situation where the difference between manufacturing and services in the average female-over-male wage ratio of innovation workers had increased to 8 percentage points ( 0.81 vs. 0.89 ) compared to 6 percentage points in 2002 (0.78 vs. 0.84$)$. For non-innovation workers, in contrast, the situation is rather the opposite: the average female-over-male wage ratio was higher in manufacturing than in services in 2002 ( 0.83 vs. 0.80 ) and by 2009 , this difference between the sectors had increased even further, to 4 percentage points ( 0.85 vs. 0.81 ).

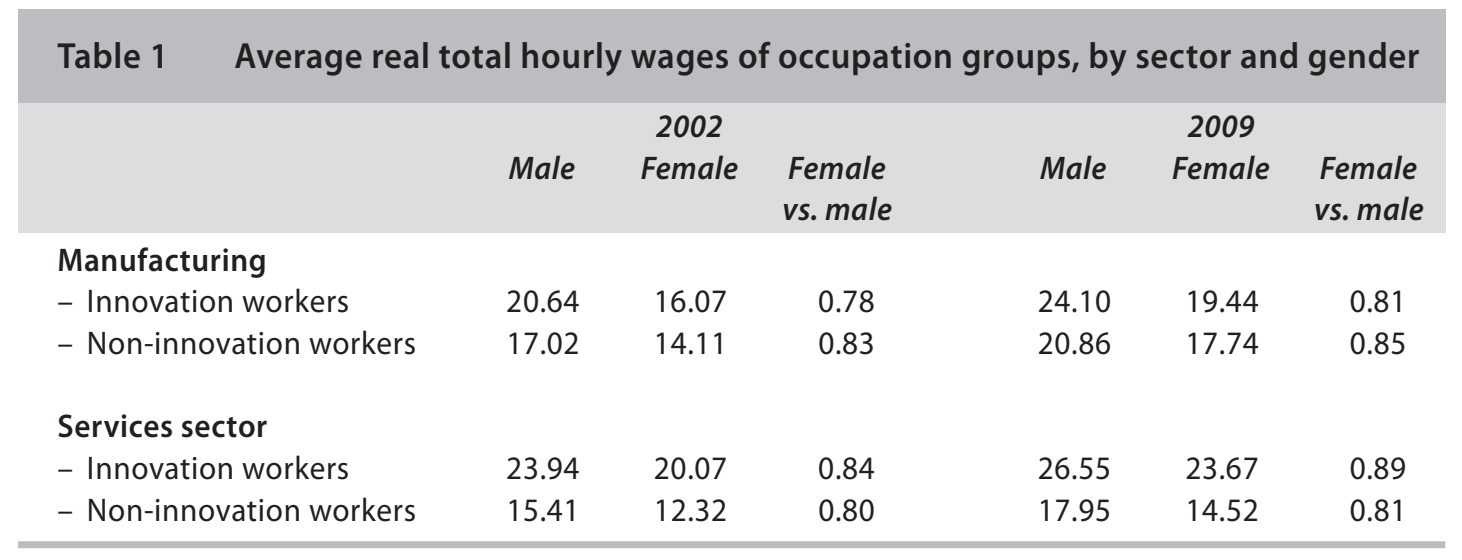

\footnotetext{
More detailed information on the classification is available from the authors upon request.

10 Görzig et al. (2011) discuss in more detail measurement issues related to intangible capital and justify why, apart from the ICT and $R \& D$ personnel, also individuals engaged in organizational work should be accounted for when creating a proxy for intangible capital.
} 
These average gender wage gaps might, however, hide substantial variation in both the size and the evolution of gender wage differentials across the wage distribution. In Figure 1 we, therefore, display the gender wage gap at various points of the worker- and occupation-specific wage distributions. ${ }^{11}$ The figure reveals that the gender wage gap is, indeed, all but constant along the wage distribution. The profiles and the changes in these profiles differ, however, quite considerably between both occupations and sectors. For innovation workers in whitecollar manufacturing jobs, the gender wage-gap profile is weakly convex - more so in 2009 than in 2002 - with slightly smaller female-over-male wage differentials among both the lowest-paid and the highest-paid compared to those located around the median wage. Innovation workers in services sector jobs, on the other hand, are characterized by a concave profile, the shape of which has, likewise, become more pronounced over the investigated time period; the gender wage gap is smallest in the middle part of the wage distribution but widens when moving towards the two tails of the distribution. In 2009, the gender wage gap among innovation workers in manufacturing jobs was lowest among the highest-paid, whilst the highest-paid innovation workers in services also faced the largest differences in male-female wages. A common feature of the two innovation worker groups, however, is that the gender wage gap has declined along the whole range of the wage distribution, albeit more so in the services sector.

Figure 1 Variation across the wage distribution in the female-over-male wage ratio, by worker and occupation groups
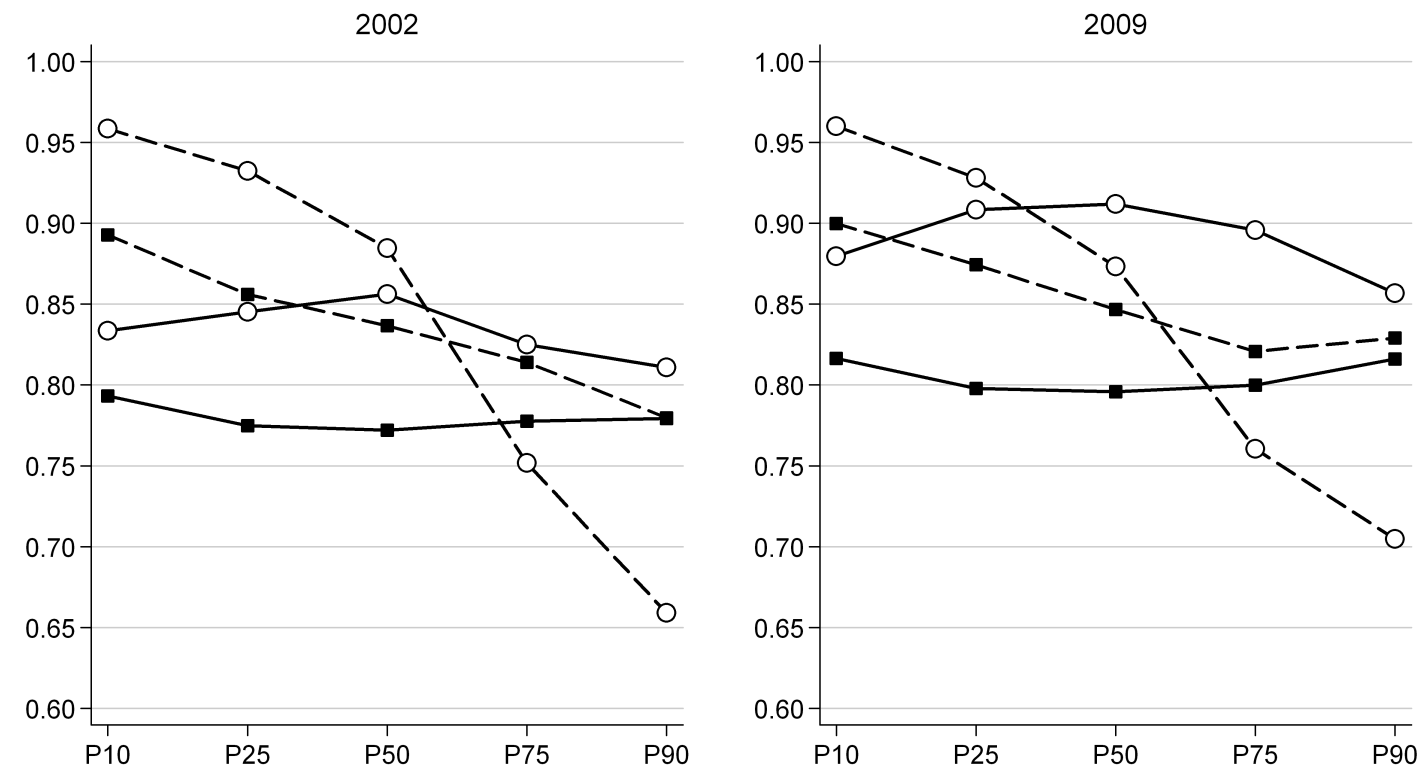

$\longrightarrow$ Manufacturing: innovation workers

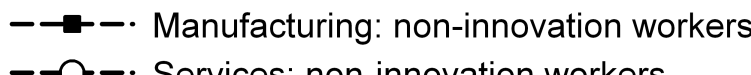

Services: innovation workers

- Services: non-innovation workers 
Among non-innovation workers, in contrast, there is a clear tendency of increasing gender wage gaps when moving up through the wage distribution. ${ }^{12}$ This tendency is much more outstanding for non-innovation workers in services than in manufacturing, though. A common feature, however, is that the overall shape of the gender wage-gap profile has remained almost unchanged between 2002 and 2009, except for the highest-paid non-innovation workers who have seen a marked decline in their gender wage gaps over this time period. As a consequence, the difference in the female-over-male wage ratio between the bottom and the top end of the wage distribution for non-innovation workers narrowed from about 11 to 7 percentage points in manufacturing and from around 30 to 25 percentage points in services.

These conspicuous differences between worker and occupation groups not only in average gender wage gaps, but also in gender wage-gap profiles across the wage distribution - and in their evolution over time - underline the importance of undertaking the decomposition of gender wage differentials along the whole wage distribution and not merely at the mean, as in most previous studies.

Table 2 presents descriptive statistics, separately by gender and worker-occupation groups, for the basic measures of human capital included in the estimated models: years of schooling, years of potential work experience, and seniority (years in current employment relationship). ${ }^{13}$ The table shows that both innovation and non-innovation workers in manufacturing are typically more educated than their counterparts in services, the only exception being female innovation workers who are, on average, almost equally well educated in both sectors. Common to the two worker groups, however, is that innovation workers tend to be more educated than non-innovation workers which, moreover, holds true for both genders.

The picture is less clear-cut when turning to general and employer-specific work experience. While innovation workers in white-collar manufacturing jobs have accumulated less general work experience than their counterparts in services sector jobs, the situation is the opposite for non-innovation workers. Innovation workers also tend to have accumulated less general work experience compared to non-innovation workers, except for males in services sector jobs. Finally, irrespective of gender, both innovation and non-innovation workers in manufacturing have, on average, a longer employment relationship with their current employer than services sector workers. Innovation workers also tend to have shorter spells of seniority than non-innovation workers, except for male services-sector workers in 2002. Broadly speaking, the overall impression is that the differences between innovation and non-innovation workers with respect to general and employer-specific work experience have declined more within sectors, especially in manufacturing, than between sectors.

Taken together, these patterns and trends had, by 2009, resulted in a situation where the average gender differences in completed years of schooling were minor or non-existent, and women had for the most part accumulated more general as well as employer-specific experience than their male counterparts. Hence, irrespective of the worker-occupation group in question men do not, on average, have a clear advantage over women when it comes to human capital endowments measured in a traditional way.

\footnotetext{
12 Several other studies have also reported increasing gender wage differentials along the wage distribution, see e.g. Albrecht et al. (2003) and Arulampalam (2007).

13 A full list of the variables used in the estimations and their definitions are given in the Appendix.
} 


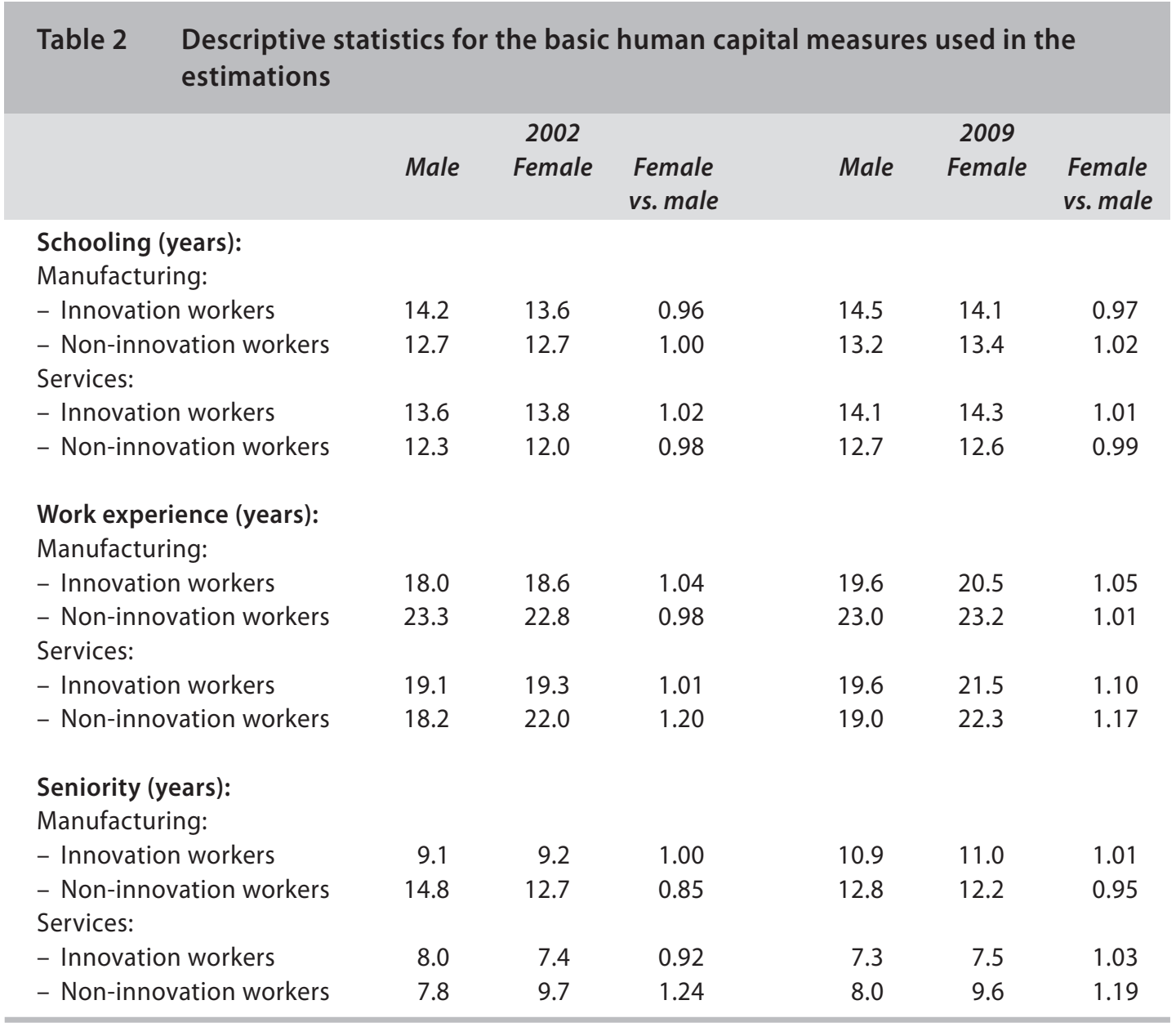

\section{$4 \quad$ Sources underlying the observed gender wage gaps - wage decomposition results}

Figures 2-4 display the results obtained when decomposing the gender wage gap in (log) total hourly wages along the whole range of the wage distribution for the two years under scrutiny, 2002 and 2009, using the methodology outlined in Section 2. ${ }^{14,15}$ By comparing the situation in 2002 to the situation almost one decade later, we can gain insight into the relative importance of the major sources underlying the wage differentials prevailing between genders at the different points of the wage distribution, but also into potential changes over time in the rela-

\footnotetext{
4 In line with previous studies using the Machado and Mata (2005) or the Melly (2005a, 2005b, 2006) decomposition method, no attempt is made to account for the possible presence of sample selection or endogeneity problems. In the present context these may arise from including women in the analysis, from confining the analysis to full-time working individuals of particular worker and occupation categories, and from relying on individual and job-related attributes which are likely to involve various choices and selections. Hence, the subsequent analysis can be characterized as a description of the gender wage gap conditional on being employed on a full-time basis as an innovation or non-innovation worker in a white-collar manufacturing or services sector job while being endowed with given individual and job-related attributes.

15 The underlying quantile regression results are available from the authors upon request.
} 
tive importance of these sources. However, in order to simplify the presentation of our results, the graphs in Figures 2-4 merely plot the contribution to the male-female wage gap of gender differences in the background characteristics accounted for in the estimations, that is, the composition effect. As the effect of the residuals is persistently negligible in our estimations, the sum of the composition effect and the price effect equals the total wage differential observed across genders. Accordingly, the contribution of gender differences in the estimated coefficients (the price effect) can be straightforwardly calculated from the graphs: the price effect equals the difference between the total gender wage differential and the composition effect. In this context it should also be noted that, while the plots of the composition effect do not display confidence intervals, the estimates are highly precise throughout the wage distribution, except for its two tails. No results are therefore shown for quantiles below 0.05 and above 0.95 .

Figures 2 to 4 plot the composition effect from two different specifications of the estimated model. The first specification, labelled 'Basic' in the figures, controls for the basic human capital related characteristics described in Table 2 above: years of schooling, years of Mincer experience and years of seniority. The second specification supplements this basic model with a set of less frequently used intangible capital related measures: the share of innovation workers in each branch, the share of innovation workers in each company, the average years of schooling of each company's workforce, and the size of each company (dummy indicators for four size categories). Detailed definitions of these variables are given in the Appendix. A major reason for extending our set of control variables beyond traditional measures of human capital is to assess the potential impact of also other types of intangible capital on the gender wage gap in general and on the wage differentials prevailing between male and female innovation workers in particular.

In comparing the multitude of gender wage-gap decomposition results produced we will, in what follows, focus on the outcome for innovation workers. More precisely, we start by contrasting the results derived for innovation workers employed in white-collar manufacturing jobs to those obtained for innovation workers in services sector jobs in search for distinct similarities and differences across sectors with respect to overall patterns and potential changes in these patterns between 2002 and 2009. Thereafter we turn to comparing the results obtained for innovation workers to those for non-innovation workers, separately for white-collar manufacturing workers and services sector workers. By comparing innovation workers to non-innovation workers within sectors we can gain further insight on whether the differences that potentially exist between innovation workers in manufacturing and those engaged in services are specific to this particular group of workers, or whether the same differences also extend to non-innovation workers, which would suggest that we are primarily faced with sector-specific rather than genuine occupation-specific discrepancies.

While the level, profile and time trend of the overall gender wage gap differ quite substantially between innovation workers in white-collar manufacturing jobs and those in services sector jobs (as discussed in Section 3), so do also the underlying sources, as is evident from Figure 2. In manufacturing, differences in basic human capital endowments between male and female white-collar innovation workers account for a minor part of the total gender wage gap. Put differently, most of the wage differential across genders is found to be explained by the price effect; that is, by male and female white-collar innovation workers being differently rewarded in manufacturing companies for similar basic human capital attributes. Moreover, this pattern has strengthened further over the investigated time period. At the same time, however, 
Figure 2 Decomposition of gender gaps in (log) total hourly wages for 2002 and 2009, innovation workers in white-collar manufacturing and services sector jobs, respectively

2002
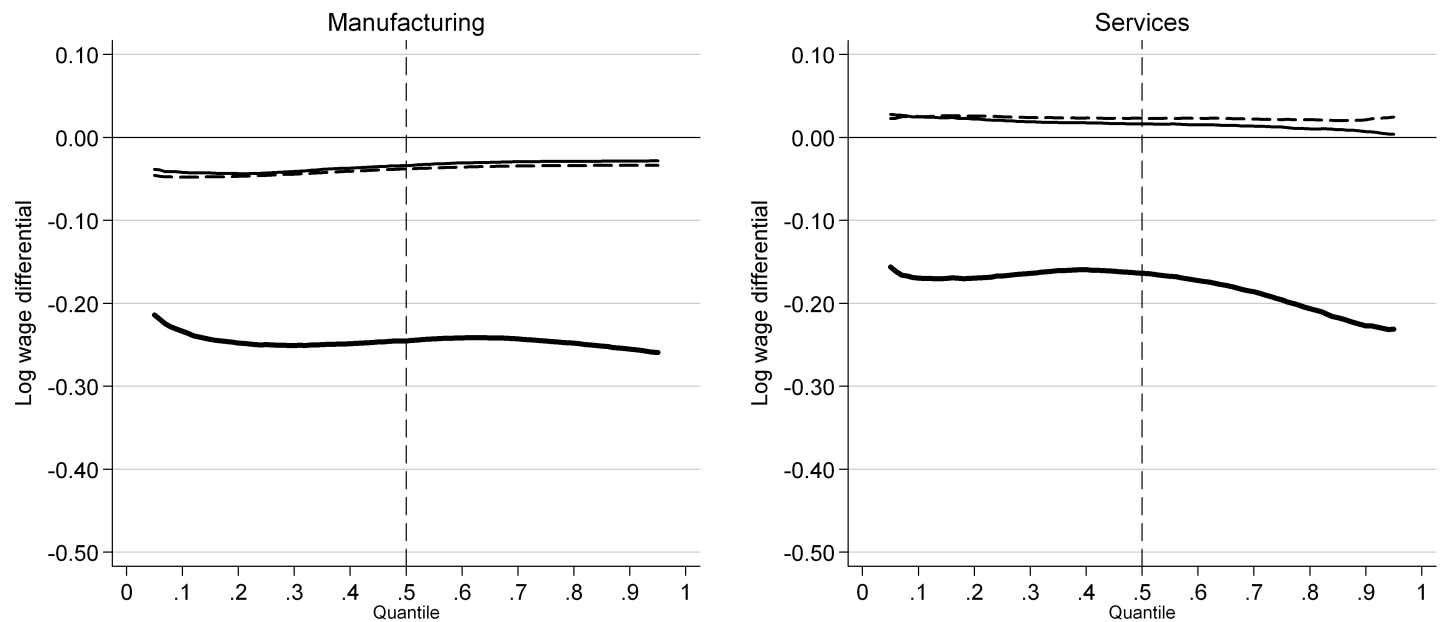

Total differential

Characteristics (basic)

----- Characteristics (extended)

2009
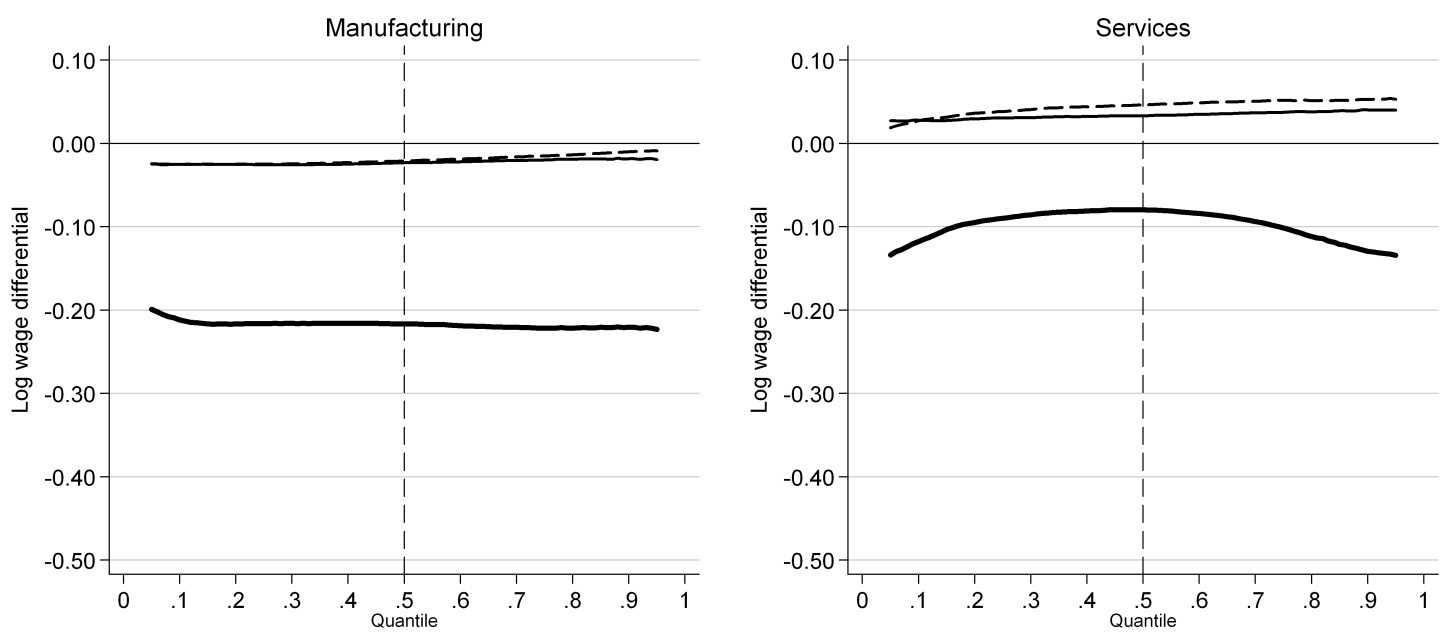

Total differential

Characteristics (basic)

Characteristics (extended)

Notes: 'Total differential' refers to the total gender wage differential. 'Characteristics (basic)' plots the composition effect when only basic human capital endowments are controlled for. 'Characteristics (extended)' shows the composition effect after controlling for a set of additional measures of intangible capital. 
the weak increase in the dominance of the price effect over the composition effect when moving up through the wage distribution has more or less disappeared.

In the services sector, on the other hand, the differences in basic human capital endowments between male and female innovation workers are positive, implying that the gender wage gap would be reversed, to the favour of women, if there were no price effect working to the favour of men. Indeed, the tendency of female innovation workers in services sector jobs possessing more wage boosting basic human capital than their male counterparts has become more pronounced in the 2000s. This positive composition effect weakens, however, when moving up through the wage distribution. By 2009, a similar situation had evolved also at the opposite tail of the wage distribution. In other words, the influence on gender wage gaps of different rewarding, to the favour of men, of similar basic human capital endowments is in relative terms markedly stronger in the bottom and top end of the wage distribution than in the middle part of the distribution.

Figure 2 also reveals that there are only marginal, if any, differences in the composition effect between the two model specifications applied (basic vs. extended). This suggests that our extended model does little to improve our ability to explain the gender wage differentials prevailing among innovation workers compared to the model including traditional measures of human capital only. Put differently, the impact of basic human capital endowments on the gender wage gaps observed at the different points of the wage distribution of innovation workers seems to hold true irrespective of differences across companies and branches in the various intangible capital related indicators accounted for in our extended specification, including the size of the company. At most, the extended model specification strengthens the patterns already displayed by the basic model specification, although more so for innovation workers in services sector jobs than for those in white-collar manufacturing jobs.

Next we turn to comparing the male-female wage decomposition results for innovation workers to those obtained for non-innovation workers by sector. Figure 3 highlights such a comparison for white-collar manufacturing workers while Figure 4 provides corresponding information for services sector workers.

As is evident from Figures 3 and 4, many of the conclusions drawn based on Figure 2 concerning similarities and differences in the factors and mechanisms underlying the gender wage gaps of innovation workers carry over to the sectors' non-innovation workers. Starting with white-collar manufacturing jobs, Figure 3 reveals that also the male-female wage differentials prevailing among non-innovation workers are explained mainly by women being less rewarded than men for similar basic human capital endowments. As for innovation workers, this pattern has strengthened over the years and had, by 2009, resulted in a situation with the composition effect actually working to the favour of women. ${ }^{16}$ However, while the increase in the dominance of the price effect over the composition effect when moving up through the wage distribution has weakened also among non-innovation workers, this pattern was outstanding still in 2009. Finally, the inclusion of additional measures of intangible capital introduces no major changes to the overall picture for non-innovation workers outlined above; rather these excess variables merely strengthen it, even more than in the case of innovation workers.

\footnotetext{
16 This may be difficult to observe from the figure, but is evident from the estimation results (that are available from the authors upon request).
} 
Figure 3 Decomposition of gender gaps in (log) total hourly wages for 2002 and 2009, innovation vs. non-innovation workers in white-collar manufacturing jobs

2002
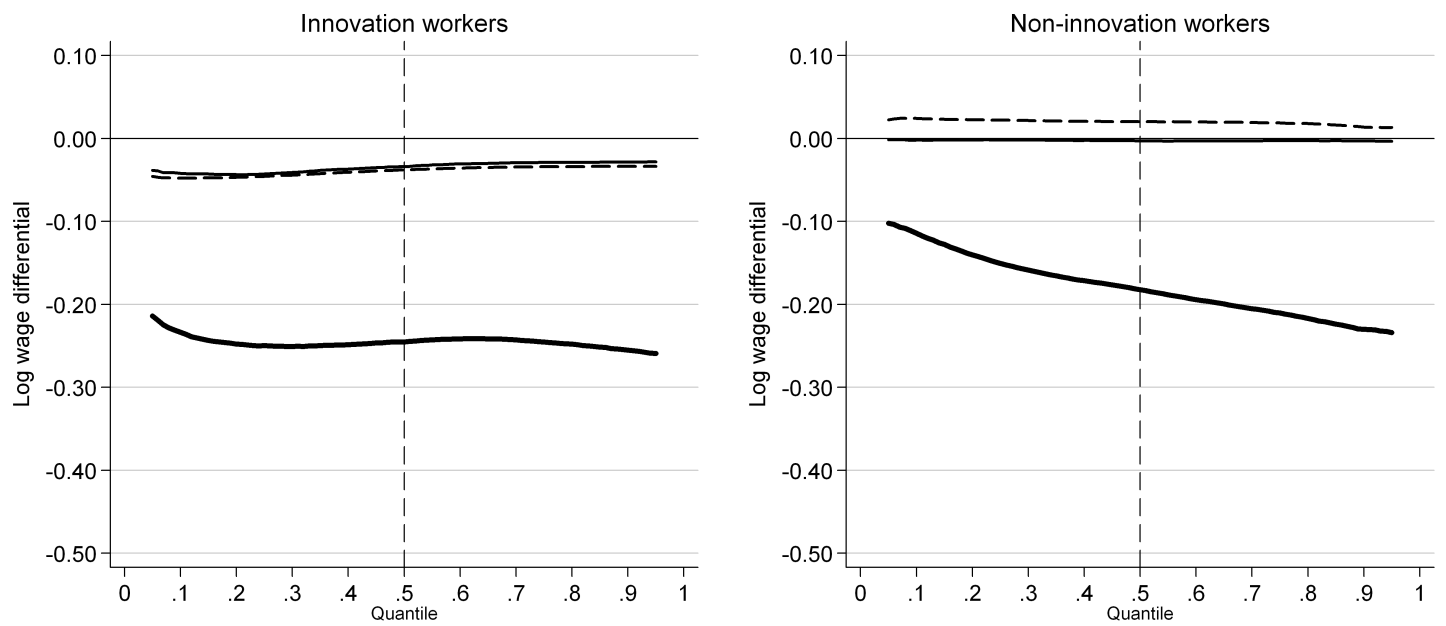

Total differential

Characteristics (basic)

Characteristics (extended)

2009
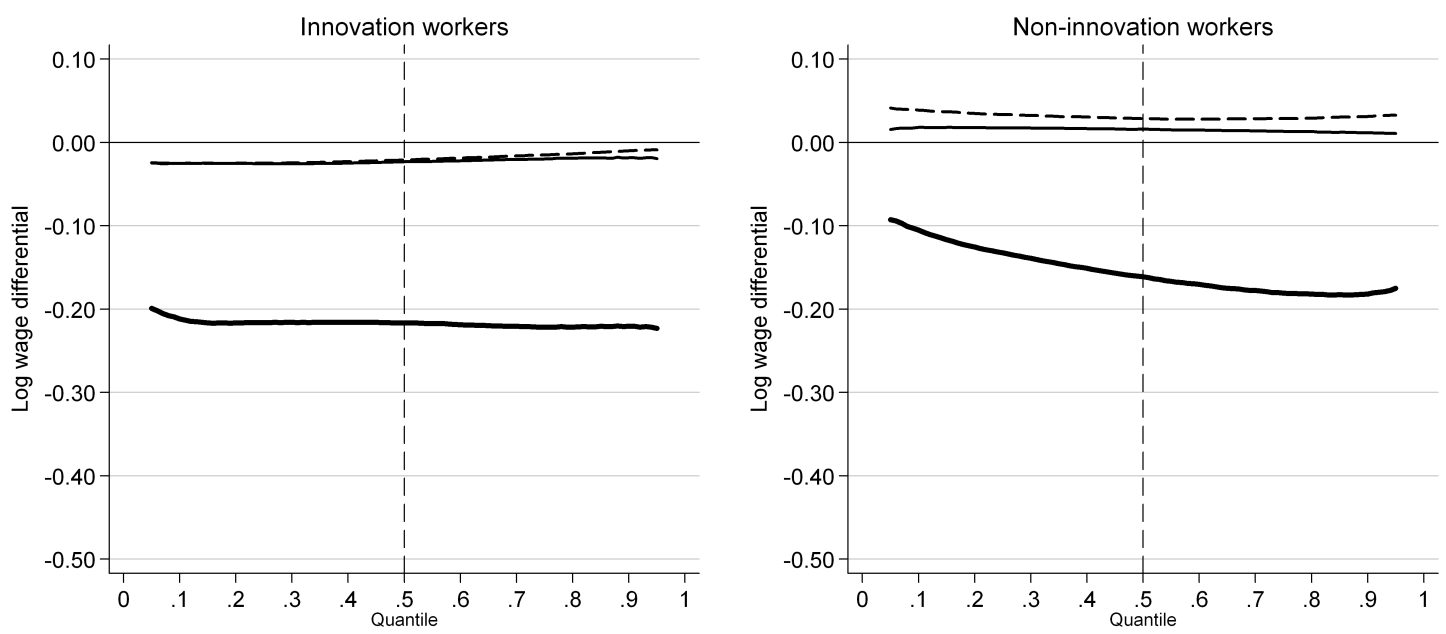

Total differential

Characteristics (basic)

----- Characteristics (extended)

Notes: See Figure 2. 
Figure 4 Decomposition of gender gaps in (log) total hourly wages for 2002 and 2009, innovation vs. non-innovation workers in services sector jobs

2002
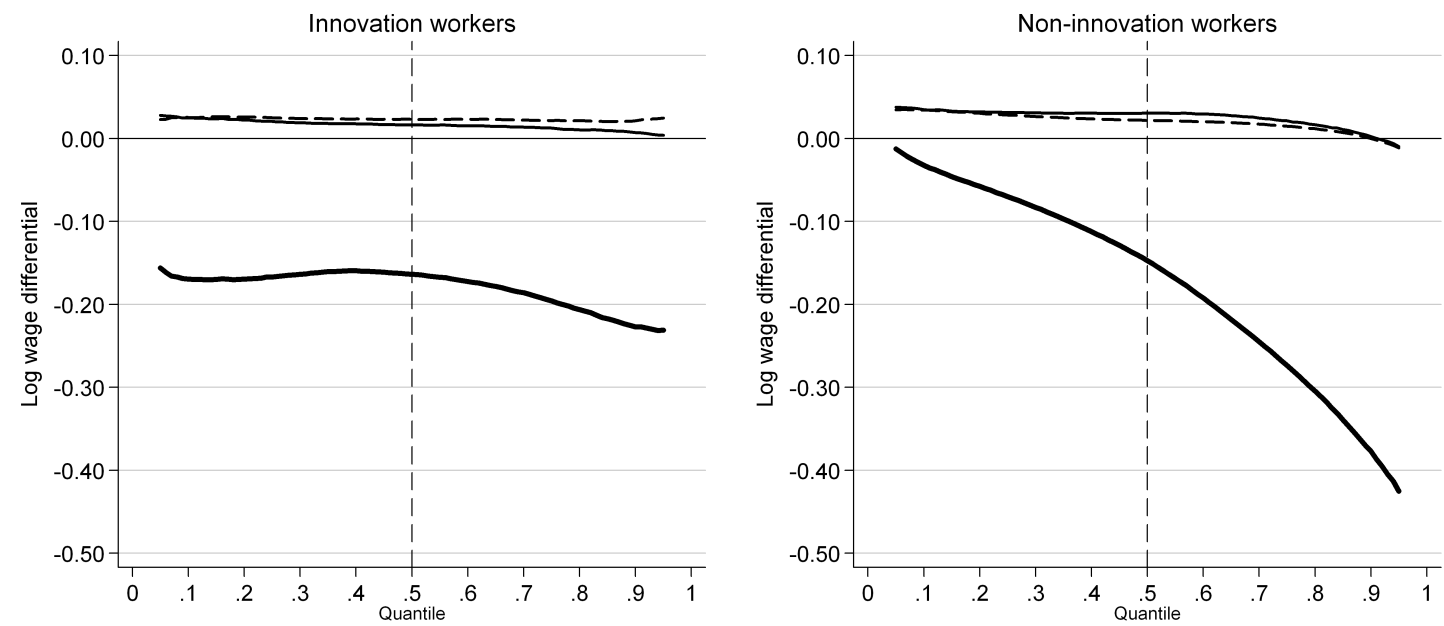

Total differential

Characteristics (basic)

Characteristics (extended)

2009
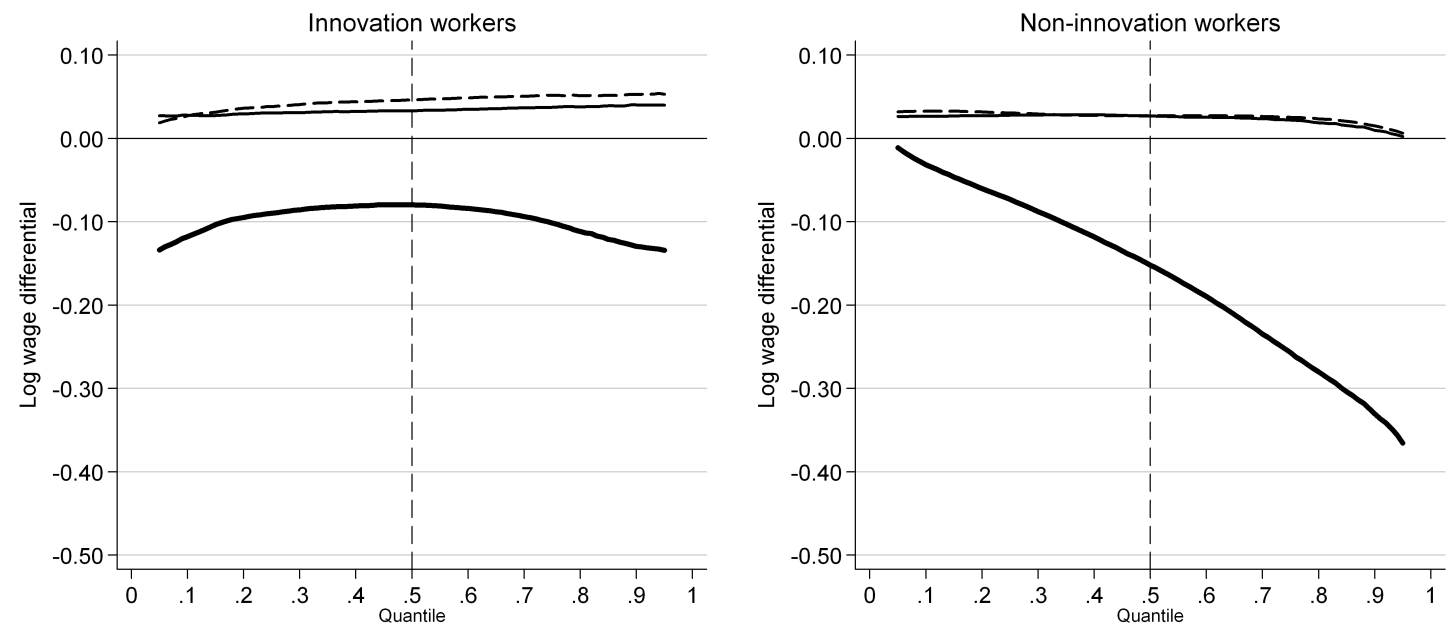

Total differential

Characteristics (basic)

Characteristics (extended)

Notes: See Figure 2. 
When it comes to the services sector, Figure 4 shows that also female non-innovation workers possess noticeably more wage-relevant basic human capital than their male counterparts. However, in contrast to the sector's innovation workers, this tendency does not seem to have strengthened over the years investigated. Another common feature of the sector's innovation and non-innovation workers is that the dominance of the price effect over the composition effect is markedly stronger in the upper half of the wage distribution. Likewise, the inclusion of additional intangible capital related variables leaves the overall pattern practically unchanged also for non-innovation workers.

Taken together, the decomposition results for non-innovation workers are in many respects in line with those obtained for the sector's innovation workers. There are, however, also noticeable differences between the two occupation groups, especially when it comes to the profile of the overall gender wage gap and the relative importance of the price effect relative to the composition effect in explaining this variation across the wage distribution. The fact that these differences are more pronounced within the services sector obviously reflects the sector's much more heterogeneous workforce as compared to the manufacturing sector's whitecollar workers. On the whole, it seems fair to argue that the occupation-specific differences in gender wage-gap patterns observed within the two sectors are clearly outpaced by the occupation-specific differences in gender wage-gap patterns prevailing between the two sectors. Overlooking sector-specific divergences might, therefore, entail the risk of drawing misleading conclusions concerning the level, profile and trend of gender wage gaps in innovation vs. non-innovation occupations.

\section{$5 \quad$ Conclusions}

This paper has examined levels, profiles and trends in gender wage gaps in the Finnish private sector. The novelty of our study is that we compare the gender wage differentials of two major occupation groups - innovation and non-innovation workers - separately for the manufacturing and the services sector and, in so doing, apply unconditional quantile regression techniques to identify key factors underlying the gender wage gaps observed along the whole wage distribution, as well as changes having occurred in these gender wage differentials between 2002 and 2009. Individuals performing ICT- or R\&D-related job tasks and individuals involved in the production of organizational competencies - i.e. management and marketing - are labelled innovation workers, whereas all other workers are classified as non-innovation workers. Distinguishing between innovation and non-innovation workers is well-justified given the distinct differences in both intangible capital intensity and wage structures characterizing these two occupation groups, differences that can be expected to also affect the gender wage gaps of the two groups. Breaking down the analysis also by sector is, in turn, highly motivated by the differences prevailing between manufacturing and services in a multitude of dimensions.

This more nuanced approach to analyzing gender wage gaps proved to unravel conspicuous differences between the worker- and occupation-specific groups under scrutiny in average gender wage gaps, in gender wage-gap profiles across the wage distribution as well as in the evolution of gender wage differentials over time. Both white-collar manufacturing and services sector workers face differently shaped gender wage-gap profiles depending on whether they 
are engaged in innovation or non-innovation job tasks. The differences between the two worker groups are, however, noticeably larger in services, one reason obviously being the sector's more heterogeneous workforce. In particular, innovation workers in white-collar manufacturing jobs are characterized by a weakly convex gender wage-gap profile while their non-innovation colleagues encounter increasing male-female wage differentials when moving up through the wage distribution. Despite this downward-sloping profile, the female-over-male wage ratio is, nonetheless, more favourable for non-innovation than for innovation workers throughout the wage distribution. While both worker groups have seen their gender wage gaps narrow, the change has been relatively larger in the top end of the wage distribution. As a consequence, the gender wage gaps are still markedly smaller among non-innovation than innovation workers in the lower half of the wage distribution, but seem to be slowly closing up between innovation and non-innovation workers in the upper half of the wage distribution.

The situation is in many respects distinctly different in private-sector services. The gender wage gaps of the sector's innovation workers have declined while their profile has turned increasingly concave. Indeed, by 2009 the male-female wage differentials observed for servicesector innovation workers were notably smaller compared to those of both innovation and non-innovation white-collar manufacturing workers across practically the whole wage distribution. The services sector's non-innovation workers, on the other hand, face a steeply downward-sloping gender wage-gap profile, which has remained almost unchanged between 2002 and 2009. The only exception to this 'cemented' gender wage-gap profile is found for the sector's highest-paid non-innovation workers, among whom the female-over-male wage gap has narrowed somewhat but is, nevertheless, still substantially larger than in any of the other worker groups. This mixture of patterns and changes over time for the services sector's innovation and non-innovation workers has resulted in a situation where the gender wage gaps of innovation workers are larger than those of non-innovation workers in the lower half of the wage distribution - albeit less so in 2009 than in 2002 - but strikingly smaller in the upper half of the wage distribution.

All in all, this comparison of innovation and non-innovation workers in relation to levels, profiles and trends of gender wage gaps clearly implies that the differences between these worker groups are more outstanding between than within sectors. In-depth analysis of the sources underlying these gender wage gaps provides further support for this contention. Moreover, the overall pattern of cross-sector differences mediated by the decompositions undertaken remains principally unchanged irrespective of the model specifications used. If anything, the inclusion of an extended set of intangible capital related control variables beyond traditional measures of human capital tend to strengthen rather than weaken the results obtained.

The decomposition results for manufacturing imply that gender differences in human capital endowments can explain only a minor part of the male-female wage differentials observed among innovation workers at the different points along the wage distribution. Among the sector's non-innovation workers, gender differences in human capital attributes actually work, albeit quite weakly, to the favour of women, indicating that female non-innovation workers tend to possess slightly more wage-relevant human capital than their male counterparts. Put differently, the gender wage gaps among both innovation and non-innovation white-collar manufacturing workers are driven, first and foremost, by women being rewarded less than men for similar endowments of human capital. However, while this unequal rewarding, to the favour of men, shows up in a similar manner along the whole range of the wage distribution for in- 
novation workers, it strengthens notably when moving up through the wage distribution for non-innovation workers.

Although the price effect comes out as the dominating source underlying the observed wage differentials across genders also among services sector workers, this dominance of the price effect over the composition effect is in many respects different from the situation faced by white-collar manufacturing workers. In particular, the composition effect is positive among both innovation and non-innovation workers. By 2009, it had strengthened further among innovation workers. Simultaneously, it had become weakly upward-sloping in shape, implying that the 'over-qualification' of female innovation workers is strongest among the highest paid. Among non-innovation workers, this 'over-qualification' tendency has remained less pronounced and is, moreover, somewhat stronger in the lower than in the upper half of the wage distribution. For both worker groups, however, the price effect more than outweighs this positive composition effect. For innovation workers its dominance is most outstanding at the two tails of the wage distribution, whereas it increases at a striking pace among non-innovation workers when moving up through the wage distribution.

In conclusion, our results suggest that sector-specific factors are a more important driving force behind the differences observed in the patterns of gender wage gaps between innovation workers in manufacturing and services, although occupation-specific factors cannot be totally dismissed. In particular, the narrowing in gender wage gaps especially in the upper half of the wage distribution of both innovation and non-innovation workers in white-collar manufacturing jobs is not primarily a question of intangible capital but of extensive adoption and implementation of new modes of pay-performance schemes which have, at least so far, benefitted mainly the sector's high-paid female workers (e.g. Asplund and Lilja, 2010). However, as the technology industry has been a for-runner in introducing new pay schemes, intangible capital have definitely had an indirect, if not direct, impact on the changes observed in gender wage-gap patterns and their underlying mechanisms. The role of intangible capital seems to be more clear-cut when it comes to services. Both the average gender wage gap and the spread in the gender gap across the wage distribution are notably smaller among innovation than noninnovation workers. Obviously, the reasons behind these differences are multifaceted, ranging from more gender segregation to slower introduction of new modes of pay schemes rewarding genuine instead of formal competencies. Taken together, our results indicate that comparisons of levels, profiles and trends of gender wage gaps, including underlying mechanisms, of innovation and non-innovation workers for too broadly defined segments of the labour market may result in misleading conclusions also concerning the role of intangible capital. 


\section{References}

Albrecht, J., A. Björklund and S. Vroman (2003): "Is There a Glass Ceiling in Sweden?", Journal of Labor Economics, 21: 145-77.

Altonji, J.G. and R.M. Blank (1999): "Race and Gender in the Labor Market", in Orley Ashenfelter and David Card (eds), Handbook of Labor Economics, Volume 3C. Amsterdam: North-Holland.

Anderson D.J., M. Binder and K. Krause (2003): "The Motherhood Wage Penalty Revisited: Experience, Heterogeneity, Work Effort and Work-Schedule Flexibility", Industrial and Labor Relations Review, 56: 273-94.

Arulampalam, W., A.L. Booth and M.L. Bryan (2007): "Is There a Glass Ceiling over Europe? Exploring the Gender Pay Gap across the Wages Distribution", Industrial and Labor Relations Review, 60: 163-86.

Asplund, R. (2010): "Sources of Increased Wage Differentials in the Finnish Private Sector", Finnish Economic Papers, 23: 43-61.

Asplund, R. and R. Lilja (2010): Wage Formation and Gender Wage Gaps: The Changing Role of Human Capital in the Finnish Technology Industry. Helsinki: ETLA Discussion Papers No. 1230.

Blau, F.D. and L.M. Kahn (1997): "Swimming Upstream: Trends in the Gender Wage Differential in 1980s", Journal of Labor Economics, 15: 1-42.

Blau, F.D. and L.M. Kahn (2000): "Gender Differences in Pay", Journal of Economic Perspectives, 14: 75-99.

Beaudry, P. and D.A. Green (2005): “Changes in US Wages, 1976-2000: Ongoing Skill Bias or Major Technological Change?", Journal of Labor Economics, 23: 548-609.

Blinder, A.S. (1973): "Wage Discrimination: Reduced Forms and Structural Estimates”, Journal of Human Resources, 8: 436-55.

Chzhen, Y. and K. Mumford (2009): Gender Gaps across the Earnings Distribution in Britain: Are Women Bossy Enough? Bonn: IZA DP No. 4331.

Corrado, C., C. Hulten and D. Sichel (2006): Intangible Capital and Economic Growth. NBER Working Paper No. 11948.

Datta Gupta, N., R.L. Oaxaca and N. Smith (2006): "Swimming Upstream, Floating Downstream: Comparing Women's Relative Wage Positions in the U.S. and Denmark", Industrial and Labor Relations Review, 59: 243-66.

Görzig, B., H. Piekkola and R. Riley (2011): Production of Intangible Investment and Growth: Methodology in INNODRIVE. INNODRIVE Working Paper No 1. Available at http://www.innodrive.org/papers.php.

Jalava, J., P. Aulin-Ahmavaara and A. Alanen (2007): Intangible Capital in the Finnish Business Sector, 19752005. Helsinki: ETLA Discussion Papers No. 1103.

Kirby, S. and R. Riley (2007): "ICT and the Returns to Schooling and Job-specific Experience", National Institute Economic Review, 201: 76-85.

Koenker, R. and G. Bassett (1978): “Regression Quantiles", Econometrica, 46: 33-50. 
Korkeamäki, O. and T. Kyyrä (2006): “A Gender Wage Gap Decomposition for Matched Employer-Employee Data", Labour Economics, 13: 611-38.

Koski, H., P. Rouvinen and P. Ylä-Anttila (2002): "ICT Clusters in Europe: The Great Central Banana and Small Nordic Potato", Information Economics and Policy, 14: 145-65.

Krueger, A. (1993): “How Computers Have Changed the Wage Structure: Evidence from Microdata, 19841989", Quarterly Journal of Economics, 108: 33-60.

Kunze, A. (2008): "Gender Wage Gap Studies: Consistency and Decomposition", Empirical Economics, 35: 63-76.

Lee, S-H. and J. Kim (2004): "Has the Internet Changed the Wage Structure Too?", Labour Economics, 11: 119-27.

Machado, J.A.F. and J. Mata (2005): "Counterfactual Decomposition of Changes in Wage Distributions using Quantile Regression", Journal of Applied Econometrics, 20: 445-65.

Maliranta, M. and P. Rouvinen (2003): Productivity Effects of ICT in Finnish Business. Helsinki: ETLA Discussion Papers No. 852.

Marrano, G.M, J. Haskel and G. Wallis (2007): What Happened to the Knowledge Economy? ICT, Intangible Investment, and Britain's Productivity Record Revisited. University of London, Queen Mary, Department of Economics Working Paper No. 603.

Melly, B. (2005a): “Public-Private Sector Wage Differentials in Germany: Evidence from Quantile Regression", Empirical Economics, 30: 505-20.

Melly, B. (2005b): "Decomposition of Differences in Distribution Using Quantile Regression”, Labour Economics, 12: 577-90.

Melly, B. (2006): Estimation of Counterfactual Distributions using Quantile Regression. University of St. Gallen, Swiss Institute for International Economics and Applied Economic Research Working Paper.

Meyersson-Milgrom, E., T. Petersen and V. Snartland (2001): “Equal Pay for Equal Work? Evidence from Sweden and a comparison with Norway and the U.S.", Scandinavian Journal of Economics, 103: 559-83.

Moreno-Galbis, E. and F.C. Wolff (2008): "New Technologies and the Gender Wage Gap: Evidence from France", Industrial Relations, 63: 317-42.

Napari, S. (2009): "Gender Differences in Early-Career Wage Growth", Labour Economics, 16: 140-58.

Oaxaca, R. (1973): "Male-Female Wage Differentials in Urban Labor Markets", International Economic Review, 14: 693-709.

Roth, F. and A.E. Thum (2010): Does Intangible Capital Affect Economic Growth. Brussels: CEPS Working Document No. 335.

Waldfogel J. (1998): "Understanding the "Family Gap" in Pay for Women with Children", Journal of Economic Perspectives, 12: 137-56. 


\section{Appendix}

Table 1Aa Descriptive statistics for total hourly wages (white-collar manufacturing workers)

\begin{tabular}{|c|c|c|c|c|c|c|}
\hline & \multicolumn{6}{|c|}{ Innovation workers } \\
\hline & \multicolumn{3}{|c|}{2002} & \multicolumn{3}{|c|}{2009} \\
\hline & Male & Female & $\begin{array}{l}\text { Female } \\
\text { vs. male }\end{array}$ & Male & Female & $\begin{array}{l}\text { Female } \\
\text { vs. male }\end{array}$ \\
\hline \multicolumn{7}{|l|}{ Level (2005 Euros) } \\
\hline Mean hourly wage & 20.64 & 16.07 & 0.78 & 24.10 & 19.44 & 0.81 \\
\hline Standard deviation & 7.38 & 5.74 & 0.78 & 8.34 & 6.91 & 0.83 \\
\hline \multicolumn{7}{|l|}{ Percentiles } \\
\hline P10 & 13.36 & 10.60 & 0.79 & 15.53 & 12.68 & 0.82 \\
\hline P25 & 15.53 & 12.03 & 0.77 & 18.21 & 14.53 & 0.80 \\
\hline P50 & 18.91 & 14.60 & 0.77 & 22.24 & 17.70 & 0.80 \\
\hline P75 & 23.92 & 18.60 & 0.78 & 28.17 & 22.54 & 0.80 \\
\hline P90 & 30.10 & 23.46 & 0.78 & 35.05 & 28.60 & 0.82 \\
\hline \multicolumn{7}{|l|}{ Interpercentiles } \\
\hline $\ln (P 90)-\ln (P 10)$ & 0.81 & 0.79 & 0.98 & 0.81 & 0.81 & 1.00 \\
\hline $\ln (P 75)-\ln (P 25)$ & 0.43 & 0.44 & 1.01 & 0.44 & 0.44 & 1.01 \\
\hline $\ln (P 90)-\ln (P 50)$ & 0.46 & 0.47 & 1.02 & 0.45 & 0.48 & 1.06 \\
\hline $\ln (P 90)-\ln (P 75)$ & 0.23 & 0.23 & 1.01 & 0.22 & 0.24 & 1.09 \\
\hline $\ln (P 75)-\ln (P 50)$ & 0.23 & 0.24 & 1.03 & 0.24 & 0.24 & 1.02 \\
\hline $\ln (P 50)-\ln (P 10)$ & 0.35 & 0.32 & 0.92 & 0.36 & 0.33 & 0.93 \\
\hline $\ln (P 50)-\ln (P 25)$ & 0.20 & 0.19 & 0.98 & 0.20 & 0.20 & 0.99 \\
\hline $\ln (P 25)-\ln (P 10)$ & 0.15 & 0.13 & 0.84 & 0.16 & 0.14 & 0.86 \\
\hline No. of observations & 52358 & 19257 & & 55712 & 20489 & \\
\hline
\end{tabular}

\begin{tabular}{|c|c|c|c|c|c|c|}
\hline & \multicolumn{6}{|c|}{ Non-innovation workers } \\
\hline & \multicolumn{3}{|c|}{2002} & \multicolumn{3}{|c|}{2009} \\
\hline & Male & Female & $\begin{array}{l}\text { Female } \\
\text { vs. male }\end{array}$ & Male & Female & $\begin{array}{l}\text { Female } \\
\text { vs. male }\end{array}$ \\
\hline \multicolumn{7}{|l|}{ Level (2005 Euros) } \\
\hline Mean hourly wage & 17.02 & 14.11 & 0.83 & 20.86 & 17.74 & 0.85 \\
\hline Standard deviation & 6.03 & 4.63 & 0.77 & 7.70 & 6.46 & 0.84 \\
\hline \multicolumn{7}{|l|}{ Percentiles } \\
\hline P10 & 11.39 & 10.17 & 0.89 & 13.53 & 12.18 & 0.90 \\
\hline P25 & 13.15 & 11.25 & 0.86 & 15.73 & 13.76 & 0.87 \\
\hline P50 & 15.44 & 12.92 & 0.84 & 18.87 & 15.97 & 0.85 \\
\hline P75 & 19.10 & 15.54 & 0.81 & 23.86 & 19.59 & 0.82 \\
\hline P90 & 24.73 & 19.28 & 0.78 & 30.70 & 25.45 & 0.83 \\
\hline \multicolumn{7}{|l|}{ Interpercentiles } \\
\hline $\ln (P 90)-\ln (P 10)$ & 0.78 & 0.64 & 0.83 & 0.82 & 0.74 & 0.90 \\
\hline $\ln (P 75)-\ln (P 25)$ & 0.37 & 0.32 & 0.87 & 0.42 & 0.35 & 0.85 \\
\hline $\ln (P 90)-\ln (P 50)$ & 0.47 & 0.40 & 0.85 & 0.49 & 0.47 & 0.96 \\
\hline $\ln (P 90)-\ln (P 75)$ & 0.26 & 0.22 & 0.83 & 0.25 & 0.26 & 1.04 \\
\hline $\ln (P 75)-\ln (P 50)$ & 0.21 & 0.18 & 0.87 & 0.23 & 0.20 & 0.87 \\
\hline $\ln (P 50)-\ln (P 10)$ & 0.30 & 0.24 & 0.79 & 0.33 & 0.27 & 0.82 \\
\hline $\ln (P 50)-\ln (P 25)$ & 0.16 & 0.14 & 0.86 & 0.18 & 0.15 & 0.82 \\
\hline $\ln (P 25)-\ln (P 10)$ & 0.14 & 0.10 & 0.71 & 0.15 & 0.12 & 0.81 \\
\hline No. of observations & 53930 & 36626 & & 52082 & 31948 & \\
\hline
\end{tabular}




\begin{tabular}{|c|c|c|c|c|c|c|}
\hline \multirow{3}{*}{ Table $1 \mathrm{Ab}$} & \multicolumn{6}{|c|}{ Innovation workers } \\
\hline & \multicolumn{3}{|c|}{2002} & \multicolumn{3}{|c|}{2009} \\
\hline & Male & Female & $\begin{array}{l}\text { Female } \\
\text { vs. male }\end{array}$ & Male & Female & $\begin{array}{l}\text { Female } \\
\text { vs. male }\end{array}$ \\
\hline \multicolumn{7}{|l|}{ Level (2005 Euros) } \\
\hline Mean hourly wage & 23.94 & 20.07 & 0.84 & 26.55 & 23.67 & 0.89 \\
\hline Standard deviation & 8.74 & 7.20 & 0.82 & 9.11 & 7.89 & 0.87 \\
\hline \multicolumn{7}{|l|}{ Percentiles } \\
\hline P10 & 15.06 & 12.55 & 0.83 & 17.69 & 15.56 & 0.88 \\
\hline P25 & 18.02 & 15.23 & 0.85 & 20.40 & 18.53 & 0.91 \\
\hline P50 & 22.03 & 18.86 & 0.86 & 24.33 & 22.18 & 0.91 \\
\hline P75 & 27.79 & 22.92 & 0.83 & 30.11 & 26.98 & 0.90 \\
\hline P90 & 35.25 & 28.59 & 0.81 & 38.37 & 32.88 & 0.86 \\
\hline \multicolumn{7}{|l|}{ Interpercentiles } \\
\hline $\ln (P 90)-\ln (P 10)$ & 0.85 & 0.82 & 0.97 & 0.77 & 0.75 & 0.97 \\
\hline $\ln (P 75)-\ln (P 25)$ & 0.43 & 0.41 & 0.94 & 0.39 & 0.38 & 0.96 \\
\hline $\ln (P 90)-\ln (P 50)$ & 0.47 & 0.42 & 0.88 & 0.46 & 0.39 & 0.86 \\
\hline $\ln (P 90)-\ln (P 75)$ & 0.24 & 0.22 & 0.93 & 0.24 & 0.20 & 0.82 \\
\hline $\ln (P 75)-\ln (P 50)$ & 0.23 & 0.19 & 0.84 & 0.21 & 0.20 & 0.92 \\
\hline $\ln (P 50)-\ln (P 10)$ & 0.38 & 0.41 & 1.07 & 0.32 & 0.35 & 1.11 \\
\hline $\ln (P 50)-\ln (P 25)$ & 0.20 & 0.21 & 1.06 & 0.18 & 0.18 & 1.02 \\
\hline $\ln (P 25)-\ln (P 10)$ & 0.18 & 0.19 & 1.08 & 0.14 & 0.17 & 1.23 \\
\hline No. of observations & 9171 & 4133 & & 13336 & 5744 & \\
\hline
\end{tabular}

\begin{tabular}{|c|c|c|c|c|c|c|}
\hline & \multicolumn{6}{|c|}{ Non-innovation workers } \\
\hline & \multicolumn{3}{|c|}{2002} & \multicolumn{3}{|c|}{2009} \\
\hline & Male & Female & $\begin{array}{l}\text { Female } \\
\text { vs. male }\end{array}$ & Male & Female & $\begin{array}{c}\text { Female } \\
\text { vs. male }\end{array}$ \\
\hline \multicolumn{7}{|l|}{ Level (2005 Euros) } \\
\hline Mean hourly wage & 15.41 & 12.32 & 0.80 & 17.95 & 14.52 & 0.81 \\
\hline Standard deviation & 7.36 & 3.97 & 0.54 & 8.74 & 5.26 & 0.60 \\
\hline \multicolumn{7}{|l|}{ Percentiles } \\
\hline P10 & 9.29 & 8.90 & 0.96 & 10.55 & 10.12 & 0.96 \\
\hline P25 & 10.56 & 9.85 & 0.93 & 12.10 & 11.23 & 0.93 \\
\hline P50 & 12.93 & 11.44 & 0.88 & 15.15 & 13.23 & 0.87 \\
\hline P75 & 17.95 & 13.50 & 0.75 & 20.99 & 15.96 & 0.76 \\
\hline P90 & 25.00 & 16.48 & 0.66 & 28.85 & 20.33 & 0.70 \\
\hline \multicolumn{7}{|l|}{ Interpercentiles } \\
\hline $\ln (P 90)-\ln (P 10)$ & 0.99 & 0.62 & 0.62 & 1.01 & 0.70 & 0.69 \\
\hline $\ln (P 75)-\ln (P 25)$ & 0.53 & 0.32 & 0.59 & 0.55 & 0.35 & 0.64 \\
\hline $\ln (P 90)-\ln (P 50)$ & 0.66 & 0.37 & 0.55 & 0.64 & 0.43 & 0.67 \\
\hline $\ln (P 90)-\ln (P 75)$ & 0.33 & 0.20 & 0.60 & 0.32 & 0.24 & 0.76 \\
\hline $\ln (P 75)-\ln (P 50)$ & 0.33 & 0.17 & 0.50 & 0.33 & 0.19 & 0.58 \\
\hline $\ln (P 50)-\ln (P 10)$ & 0.33 & 0.25 & 0.76 & 0.36 & 0.27 & 0.74 \\
\hline $\ln (P 50)-\ln (P 25)$ & 0.20 & 0.15 & 0.74 & 0.23 & 0.16 & 0.73 \\
\hline $\ln (P 25)-\ln (P 10)$ & 0.13 & 0.10 & 0.78 & 0.14 & 0.10 & 0.75 \\
\hline No. of observations & 47552 & 114930 & & 62213 & 130101 & \\
\hline
\end{tabular}


Description of variables used in the estimations

(Log) real total hourly wage: Total hourly wages are calculated by dividing total monthly earnings by regular monthly working hours. The wage variable thus adds to the basic monthly earnings various types of bonuses (such as merit pay) and possible fringe benefits. The total hourly wages are deflated by the official consumer price index (CPI).

Years of schooling: Years of schooling are calculated by using information on education levels as follows: i) elementary education: 9 years of schooling, ii) upper secondary level education: 12 years of schooling, iii) lowest level of tertiary education: 13 years of schooling, iv) lowerdegree tertiary education: 15 years of schooling, v) higher-degree tertiary education: 17 years of schooling, vi) doctorate or equivalent tertiary education: 19 years of schooling. This transformation adheres to the key developed by Statistics Finland.

Years of work experience: Work experience refers to potential experience calculated as age minus years of schooling minus 7 (age of school start). An additional year (due to army conscript which lasts from six months up to one year) is added for men.

Years of seniority: Years spent with the current employer.

Share of innovation workers in the branch: Number of individuals in the branch performing ICT- or R\&D-related job tasks or involved in management and marketing divided by the total number of individuals in the branch. Calculated separately for manufacturing and services.

Share of innovation workers in the company: Number of individuals in the company performing ICT- or R\&D-related job tasks or involved in management and marketing divided by the total number of individuals in the firm.

Personnel's average years of schooling: Calculated from information on years of schooling (as defined above) of the individuals employed in the company.

Firm size: Four categories: i) personnel $<50$, ii) personnel $\geq 50 \&$ personnel $<100$, iii) personnel $\geq 100$ \& personnel $<300$, iv) personnel $\geq 300$. 



\section{Aikaisemmin ilmestynyt ETLAn Keskusteluaiheita-sarjassa Previously published in the ETLA Discussion Papers Series}

No 1228 Eija Niskanen - Yoshio Kakeo - Silvana Petkovic - Karen Severns, Japanese - Baltic Sea Region Film Co-production: Japanese Views. 19.11.2010. 108 p.

No 1229 Markku Kotilainen - Nuutti Nikula, Why do Firms Invest in the Baltic Sea Region? 19.11.2010.36 p.

No 1230 Rita Asplund - Reija Lilja, Wage Formation and Gender Wage Gaps: The Changing Role of Human Capital in the Finnish Technology Industry. 03.12.2010. 22 p.

No 1231 Tuomo Nikulainen - Hannele Salminen - Pekka Ylä-Anttila, Ammattikorkeakoulujen asema ja uudistuminen - Taustakyselyn tuloksia. 01.12.2010. $28 \mathrm{~s}$.

No 1232 Ilkka Ylhäinen, Persistence of Government Funding in Small Business Finance. 13.12.2010. 33 p.

No 1233 Antti-Jussi Tahvanainen - Tuomo Nikulainen, Tutkimusympäristö muutoksessa - Tutkijoiden näkemykset SHOK:n, korkeakoulukeksintölain ja yliopistolain vaikutuksista. 22.12.2010. $18 \mathrm{~s}$.

No 1234 Antti-Jussi Tahvanainen - Tuomo Nikulainen, Commercialiazation at Finnish Universities - Researchers' Perspectives on the Motives and Challenges of Turning Science into Business. 10.01.2011. 47 p.

No 1235 Heli Koski - Mika Pajarinen, Do Business Subsidies Facilitate Employment Growth? 04.01.2011. 20 p.

No 1236 Antti-Jussi Tahvanainen - Raine Hermans, Making Sense of the TTO Production Function: University Technology Transfer Offices as Process Catalysts, Knowledge Converters and Impact Amplifiers. 11.01.2011. $40 \mathrm{p}$.

No 1237 Jukka Lassila - Tarmo Valkonen, Julkisen talouden rahoituksellinen kestävyys Suomessa. 11.01.2011.28 S.

No 1238 Martin Kenney - Bryan Pon, Structuring the Smartphone Industry: Is the Mobile Internet OS Platform the Key. 10.02.2011. 24 p.

No 1239 Mika Maliranta-Reijo Mankinen - Paavo Suni-Pekka Ylä-Anttila, Suhdanne- ja rakennekriisi yhtä aikaa? Toimiala- ja yritysrakenteen muutokset taantumassa. 17.02.2011. $20 \mathrm{~s}$.

No 1240 Jyrki Ali-Yrkkö - Petri Rouvinen - Timo Seppälä-Pekka Ylä-Anttila, Who Captures Value in Global Supply Chains? Case Nokia N95 Smartphone. 28.02.2011. 22 p.

No 1241 Antti Kauhanen - Sami Napari, Gender Differences in Careers. 9.03.2011. 31 p.

No 1242 Mika Pajarinen - Petri Rouvinen - Pekka Ylä-Anttila, Omistajuuden vaikutus suomalaisen työllisyyden kasvuun ja pysyvyyteen. 16.03.2011.27 s.

Elinkeinoelämän Tutkimuslaitoksen julkaisemat "Keskusteluaiheita" ovat raportteja alustavista tutkimustuloksista ja väliraportteja tekeillä olevista tutkimuksista. Tässä sarjassa julkaistuja monisteita on mahdollista ostaa Taloustieto Oy:stä kopiointi- ja toimituskuluja vastaavaan hintaan.

Papers in this series are reports on preliminary research results and on studies in progress. They are sold by Taloustieto Oy for a nominal fee covering copying and postage costs.

Julkaisut ovat ladattavissa pdf-muodossa osoitteessa: www.etla.fi/julkaisuhaku.php

Publications in pdf can be downloaded at www.etla.fi/eng/julkaisuhaku.php

ETLA

Elinkeinoelämän Tutkimuslaitos

The Research Institute of the Finnish Economy

Lönnrotinkatu 4 B

00120 Helsinki
Puh. 09-609 900

Fax 09-601 753

www.etla.fi

etunimi.sukunimi@etla.fi

ISSN 0781-6847 